\title{
「サステイナブルな社会を実現するための診断・監視・保全技術」
}

概要 : 2015 年 9 月の国連サミットで，持続可能な開発目標 (Sustainable Development Goals：SDGs）が採択さ れ，世界各国でサステイナブルな社会を実現するための取り組みが行われており，我が国においても産学 官民が一体となり SDGs 達成のための様々な活動が行われております。一方，診断・監視・保全技術は社 会基盤を維持するための重要な技術として，電気・電子分野に限らず，社会を支える様々な分野において 研究・開発が進んでおります。当然ながらこれらの技術の発展は, SDGs の達成には久かせない重要な要 素の一つであり, 研究者・技術者の研究活動の重要性は増すばかりです。本フォーラムでは, 情報, 電気 電子, 機械, 建設土木, 獣医学など, 多岐に渡る分野における最新の技術・研究動向について, 学界・産 業界の専門家から幅広く御講演頂きます。皆様のご参加を心よりお待ち致しております。

日時：2021年 11 月 30 日（火） 10:00〜 16:30

会場 : 計算科学センタービル $2 \mathrm{~F}$ セミナールーム 1 および ZOOM によるオンライン参加 のハイブリッド開催 干650-0047 神戸市中央区港島南町 7-1-28（「計算科学センター」駅（ポートライナー）より徒歩約 3 分） TEL: 078-599-5020, URL: https://www.j-focus.or.jp/center/

注意事項 : 新型コロナウイルスの感染状況により，オンライン参加のみへの変更，または会場を変更する場合が あります。その場合には，おおむね開催 2 週間前までに，申込者宛に電子メールにて連絡します。

\section{プログラム :}

1. 10:00〜 10:05 開会・主催者挨拶 下野 誠通（横浜国立大学）

2. 10:05〜11:00 Society 5.0 時代のサイバーリスクを踏まえた診断と監視 神薗 雅紀 氏（デロイトトーマツサイバー合同会社

11:00〜11:05 休憩

・執行役員 CTO 兼サイバーセキュリティ先端研究所所長)

3. 11:05 11:40 計算科学振興財団と産業利用向け FOCUS スパコンのご紹介

高橋 太一 氏（公益財団法人計算科学振興財団 普及促進グループ・課長）

4. 11:40〜12:00 CAE ソリューションズのご紹介

田倉 啓之 氏（株式会社 CAE ソリューションズ FOCUSテクニカルセンター）

12:00 13:30 昼休䄭

5. 13:30 14:25 Using the Multi-modal Vibration Based Piezoelectric Energy Harvesters to Power Microelectronics Sensors Dr. Iman Izadgoshasb (Lecturer in Mechanical Engineering, Faculty of Science and Engineering, Southern Cross University)

6. 14:25～15:20 走行型計測車両 MIMM-R によるトンネル点検・診断イノベーション

安田 亨氏 氏（パシフィックコンサルタンツ株式会社 交通基盤事業本部・技術理事)

15:20〜15:30 休憩

7. 15:30〜 16:25 牛における人工授精適期と分娩予測の指標の現在と未来

三浦 亮太朗 氏（日本獣医生命科学大学 獣医学部 獣医学科・講師）

8. 16:25 16:30 主催者挨拶・閉会 柏尾 知明 (近畿大学)

司会進行：牟田神東 達也（かんでんエンジニアリング）

テキスト：PDFのテキストを配布

$\begin{array}{cccc}\text { 参 加 費: 会員 (正員) } & ¥ 7,000 \text { (税込) } & \text { 非会員 (一般) } & ¥ 8,000 \text { (税込) } \\ \text { 会員 (准·学生員) } & ¥ 2,000 \text { (税込) } & \text { 非会員 (学生) } & ¥ 3,000 \text { (税込) }\end{array}$

申込方法：ホームページからお申込みください。: https://www.iee.jp/blog/forum/ 申込フォームの備考欄に，参加方法（現地参加，または，オンライン参加）を入力してください。 総定員 250 名（会場定員 20 名）に達し次第，それぞれ締め切らせていただきます。定員に達した場合， 会員を優先しますので，非会員の方は，是非この機会に電気学会へのご入会をご検討ください。

問合せ先 : 大屋 英稔 (東京都市大学) E-mail : md (at) zidane.ee.uec.ac.jp

参加費支払い方法 : 現地参加，オンライン参加に関わらず，Web からのクレジットカードによるお支払いとなり ます。決済後はWeb サイトにて領収書が発行されます。

主催：一般社団法人 電気学会 産業応用部門 産業計測制御技術委員会（委員長：下野 誠通）

共 催 : 同技術委員会 診断・監視・保全の基盤技術に関する調査専門委員会（委員長：柏尾 知明） 